\title{
GIS-based model for determining the optimal potential of co-digestion mixtures in the Spanish Iberian Peninsula
}

\author{
A. González-Martínez ${ }^{1}$, M. de Simón-Martín ${ }^{1}$, A.M. Diez Suárez ${ }^{1}$, Á. de la Puente-Gi1 ${ }^{1}$, \\ M.Á. Ramos Malmierca ${ }^{1}$ and L. Álvarez-de Prado ${ }^{2}$ \\ ${ }^{1}$ Dep. Area of Electrical Engineering \\ Energy Resources' Smart Management (ERESMA) Research Group \\ School of Mining Engineering, Universidad de León (Spain) \\ Campus de Vegazana s/n, Universidad de León, 24071 - León \\ E-mail: alberto.gonzalez@unileon.es, miguel.simon@unileon.es, ana.diez.suarez@unileon.es, \\ apueg@unileon.es, mramom01@estudiantes.unileon.es \\ ${ }^{2}$ Dep. Area of Cartographic, Geodesic and Photogrammetric Engineering \\ Energy Resources' Smart Management (ERESMA) Research Group \\ School of Mining Engineering, Universidad de León (Spain) \\ Campus de Vegazana s/n, Universidad de León, 24071 - León \\ E-mail: laura.alvarez@unileon.es
}

\begin{abstract}
Agricultural and livestock biogas exploitation trough co-digestion power plants is still poorly deployed in Europe -e.g., in Spain, this Renewable Energy Source (RES) represents only the $0.17 \%$ of installed RES capacity- although most authors agree and even EU Directive 2009/28/EU stipulates that biogas and this type of energy can contribute to a reduction of at least $35 \%$ of greenhouse gas emissions. Furthermore, biogas can be used to upgrade gas pipelines, which results of great interest. Nevertheless, it has been observed that the biogas production its underrated in many EU member states, especially in Spain, and it still has a very low penetration rate in the energy mix. Most currently installed co-digestion power plants in our country show low installed capacity values (the $66 \%$ of installed co-digestion power plants have a rated power less than $500 \mathrm{~kW}$ ) and are restricted to local resources.
\end{abstract}

In this paper, through a Geographical Information System (GIS) approach, 8 different co-digestion mixtures have been evaluated and the most profitable ones have been optimized for the Spanish Iberian Peninsula to set their real biogas generation potential according to the geographical distribution of the resources. Moreover, for each different mixture, optimal clusterization have been proposed, according to maximum potential generation and minimum transport cost ratios. This analysis results fundamental for the optimal deployment of co-digestion power plants in Spain and the adequate allocation of RES.

Results show that the most feasible co-digestion mixtures available in the Spanish Iberian Peninsula are based on slurry, glycerine and agricultural residuals, and 4 mixtures show a great energetic potential, estimated in more than $277 \mathrm{MW}$ of electrical power capacity in co-digestion power plants economically feasible. The Spanish Iberian Peninsula potential is estimated in the range from $175 \mathrm{MW}$ to $550 \mathrm{MW}$.

\section{Keywords}

Anaerobic digestion, biogas, GIS, optimization, clustering.

\section{Introduction}

The Organisation for Economic Co-operation and Development (OECD) defines waste as "matters that, generated in the activities of production and consumption, do not reach in the context in which they produce any economic value, either because there is no adequate technology for their use or because there is no market for the recovered products" [1].

The production of biogas from biomass by anaerobic digestion has developed significantly in the last twenty years in many European countries, but in Spain [2]. The production of biogas in a more sustainable way by a smart intensification of crop rotation, use of agroindustrial wastes, and recycling the nutrients of byproducts is being planted by the European authorities. Biogas from digestion has increasingly been considered a feasible alternative to the energy from fossil fuels, among the RES.

Anaerobic digestion is a biological process in which organic matter, in the absence of oxygen, and by the action of a group of specific bacteria, is broken down into gaseous products or "biogas" (above all $\mathrm{CH}_{4}, \mathrm{CO}_{2}, \mathrm{H}_{2}$ and $\mathrm{H}_{2} \mathrm{~S}$ ) and in digest, which is a mixture of mineral products $(\mathrm{N}, \mathrm{P}, \mathrm{K}, \mathrm{Ca}$, etc.) and hard degradation compounds [3]. 
Anaerobic digestion can be applied, among others, to livestock and agricultural waste (slurry, manure, agricultural residues or surplus crops, etc.), as well as waste from the processing industries of these products. These residues can be treated independently or as mixture thanks to co-digestion processes [4].

Obtained biogas from these described co-digestion processes contains a high percentage of $\mathrm{CH}_{4}$ (usually between $50 \%$ and $70 \%$ in volume), so it is susceptible to be used for energetic purposes, mainly by combustion processes in industrial engines, turbines or boilers, either alone or mixed with another fuel [5].

Supervised anaerobic digestion processes result essential for the reduction of greenhouse gas emissions, the energetic use of organic waste and the valorization of the fertilizer potential of the treated products [3].

The main benefits associated with anaerobic digestion can be summarized as:

- Significant reduction of bad odors.

- Mineralization.

- Renewable energy generation.

- Reduction of greenhouse gas emissions derived from the reduction of uncontrolled emissions of $\mathrm{CH}_{4}$, (which produces a greenhouse effect quantified in more than 20 times more dangerous for the environment than the $\mathrm{CO}_{2}[6]$ ).

- Reduction of emitted $\mathrm{CO}_{2}$ gasses thanks due to fossil fuel savings [7].

However, unlike other RES, the electric power generated from co-digestion processes is associated with a series of uncertainties, which makes it difficult to generalize the technical or economic potential at the national or regional level. This is mainly due to the diversity of potentially suitable raw material substrates, the geographical distribution of the resource and the generation scale [8].

Currently in Spain, there are registered 79 installations for the production of electrical energy from waste processed by anaerobic digestion processes, with a cumulated power capacity of more than $84 \mathrm{MW}$ [9]. More than a half of the installations have an installed rated power lower than $500 \mathrm{~kW}$ due to some advantageous conditions in the previous legal framework, not in force anymore [10]. It should be observed that, unlike other RES, the energy resource in this case is limited and the exploitation conditions can modify the global efficiency, i.e., the resource which is exploited in an un-efficient is not available to be exploited in a more efficient parallel process. The classical approach for planning the deployment of this type of power plants has been conditioned by the financial remuneration framework (usually based on the installed capacity trying to promote small size power plants), obviating the limitation of the resource. Thus, an approach based on the optimal clustering of the resources is needed.

\section{Materials and methods}

The "PROBIOGÁS" project [11], carried out the stock analysis and estimation of agro-industrial resources for biogas production in Spain by compiling a database of raw materials. Its purpose is to conduct "the study of the development of sustainable systems of production and use of biogas in agroindustrial environments, as well as the demonstration of its viability and promotion in Spain". According to this data source, Figure 1 has been elaborated showing the most available substrates in Spain for co-digestion purposes.

On the other hand, Table I shows the specific potential of biogas production for each raw farming matter. It can be observed that glycerine is the raw matter with the highest specific potential for biogas production, followed by flours, cow dung and agricultural residuals. However, these high potential raw matters show very low availability in Spain, and thus, mixtures of lower potential, but higher availability, raw matters (e.g., pork slurry or cereal straw) must be considered. Moreover, raw resources are not equally geographically distributed, making the optimal selection for electrical generation not evident.



Figure 1. Most available substrates in Spain (data from [11]).

Table I. - Specific biogas production potential for each source of farming matter. Source: [12].

\begin{tabular}{|l|r|}
\hline \multicolumn{1}{|c|}{ MATTER } & $\begin{array}{c}\text { BIOGAS POTENTIAL } \\
\left(\mathbf{N m}^{3} / \mathbf{t}\right)\end{array}$ \\
\hline Pork slurry & 10.82 \\
\hline Chicken dung & 31.28 \\
\hline Cow dung & 115.59 \\
\hline Flours & 469.00 \\
\hline Agricultural residuals & 106.00 \\
\hline Whey & 37.00 \\
\hline Glycerin & 686.00 \\
\hline
\end{tabular}

Many co-digestion models can be found in the scientific literature, including dynamic and non-dynamic models. The dynamic models can predict the evolution of processes continuously and are based on several ordinary differential equations (ODE) considering mass-balances. In the present study it has been applied the dynamic model presented by Y.R. Chen in [13] and implemented by $\mathrm{P}$. Harris in a software tool freely available online [14], which allows the determination of biogas potential of the co-digestion of a mixture of multiple substrates, 
taking into account mainly the volatile solids, the operating temperature and the hydraulic dwell time supposing a continuous type reactor and daily feeding conditions. This model has been widely validated in other co-digestion studies, such as [15], where different domestic and industrial mixtures are tested.

Table II shows the 8 mixtures selected in this study which showed best results considering the most available raw materials in Spain and the estimations from the Cheng's model. Many mixtures have been discarded due to limitations biogas production depending on the percentage of water content in the manures or the flow rates of the digester [16].

Table II. - Estimated production of biogas for each selected co-digestion mixture. Source: [12], [17].

\begin{tabular}{|c|l|r|}
\hline ID & \multicolumn{1}{|c|}{ BREAKDOWN } & $\begin{array}{c}\text { BIOGAS } \\
\text { PROD. } \\
\text { (Nm }\end{array}$ /t) \\
\hline 1 & $\begin{array}{l}\text { 62\% Pork slurry } \\
38 \% \text { Chicken dung and cow dung }\end{array}$ & 20.17 \\
\hline 2 & $\begin{array}{l}\text { 95\% Pork slurry, chicken and cow dung } \\
5 \% \text { Flours }\end{array}$ & 42.99 \\
\hline 3 & $\begin{array}{l}90 \% \text { Pork slurry, chicken and cow dung } \\
10 \% \text { Flours }\end{array}$ & 65.40 \\
\hline 4 & $\begin{array}{l}80 \% \text { Pork slurry, chicken and cow dung } \\
20 \% \text { Agricultural residuals }\end{array}$ & 31.76 \\
\hline 5 & $\begin{array}{l}\text { 95\% Pork slurry, chicken and cow dung } \\
5 \% \text { Glycerine }\end{array}$ & 31.36 \\
\hline 6 & $\begin{array}{l}90 \% \text { Pork slurry, chicken and cow dung } \\
10 \% \text { Glycerine }\end{array}$ & 87.11 \\
\hline 7 & $\begin{array}{l}45 \% \text { Cow dung } \\
55 \% \text { Whey }\end{array}$ & 10.60 \\
\hline 8 & $\begin{array}{l}15 \% \text { Cow dung } \\
85 \% \text { Whey }\end{array}$ & 14.60 \\
\hline
\end{tabular}

For power generation from co-digestion processes, it has been considered that (i) $1 \mathrm{Nm}^{3}$ biogas contains $65 \%$ of $\mathrm{CH}_{4}$ on average; (ii) the calorific value of $\mathrm{CH}_{4}$ is estimated in $5750 \mathrm{kcal} / \mathrm{Nm}^{3}$; (iii) the power plants' equivalent hours of operation have been set in $6000 \mathrm{~h}$ per year; and (iv) the average thermal performance of the gas engines for electric generation has been considered $40 \%$.

In order to find optimal clusters for the best exploitation of co-digestion mixtures, the raw matters database has been introduced in a GIS system and the resources have been geo-referenced and the global potential is calculated. Then, the regions with the highest potential for electric energy generation from the 8 different mixtures have been defined and clusters around them have been set. These clusters consider a minimum transport cost criterion [18]. Finally, economically feasible co-digestion exploitation for electric energy generation are defined by applying a minimum threshold and, thus, resources for distributed generation and centralized generation can be distinguished.

Therefore, different criteria in a sequenced form were applied. First, a threshold of minimum electric power potential is established to differentiate cluster candidate regions for each co-digestion mixture. Those regions with a power generation potential higher than the threshold $(2 \mathrm{MW})$ are clustered considering a maximum distance with the cluster's centroid of $200 \mathrm{~km}$ in order to remain transport costs minimum. Non-clustered regions are then considered for distributed generation and hot areas are identified by calculating the energy potential density. On the other hand, the electric power generation potential is recalculated in the cluster areas maximizing the mixtures' input materials exploitation. The effects of the constraining raw materials are then minimized. It should be noticed that, for the same geographical area, different mixtures can coexist, even if they have a common substrate, provided that one of them does not exhaust the substrate in its entirety or in such a proportion to prevent their coexistence. Moreover, in case of a matter depletion in a certain area, the most profitable one (which could conduct to a power plant with a higher installed rated power will be selected).

\section{Results and discussion}

Figures 2-7 show the optimal clusterization results for mixtures 1, 4, 5, 6, 7 and 8. Mixtures 2 and 3 have demonstrated not to have enough energy generation potential, and they were discarded in the following analysis.

Mixture 1 (62\% of pork slurry and $38 \%$ of chicken dung and cow dung) offers the best results in the analysis, very favored by the existence of a very important swine hut in the Northwest and in the center parts of Spain. Figure 2 indicates the most susceptible regions for the use of the mixture 1, with 5 clusters for centralized generation, including the estimated potential of electric energy generation.

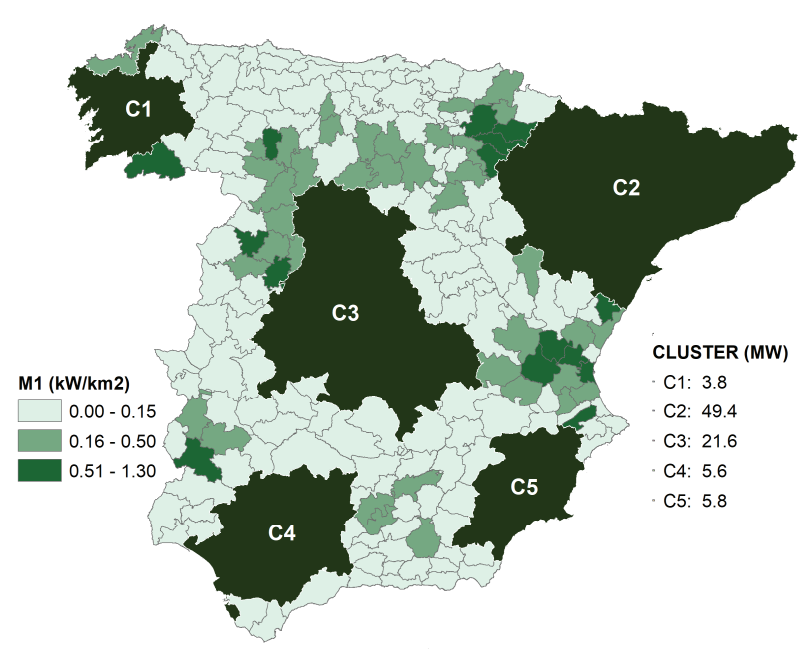

Figure 2. Geographical distribution of the electric power generation potential for co-digestion mixture 1 .

Estimated electric power generation capacity for the clusters is in the range from $3.8 \mathrm{MW}$ to $49.4 \mathrm{MW}$, which means that a high potential for installing centralized codigestion based power plants exist (witch can take 
advantages of economy scale benefits and better efficiencies in the power generation [19]).

On the other hand, Figure 3 show the results of deploying mixture $4(80 \%$ of pork slurry, chicken dung and cow dung and $20 \%$ of agricultural residuals). It can be observed that the coexistence of an intensive livestock farming added to an important agricultural and agro-industrial farm in Spain help to take advantage of this mixture. Furthermore, clustered electric power generation potential comprises up to $86.6 \mathrm{MW}$ with an average potential per cluster of $12.37 \mathrm{MW}$.



Figure 3. Geographical distribution of the electric power generation for co-digestion mixture 4 .

Mixture 5 (95\% of pork slurry, chicken dung and cow dung and $5 \%$ of glycerine), which electric power generation potential geographic distribution can be seen in Figure 4, arises with force due to the installation of biodiesel companies that generate, as a sub-product, large amounts of glycerine. The excellent properties of the glycerine as a raw material in digestion and co-digestion plants boost significantly the performance of these codigestion plants.



Figure 4. Geographical distribution of the electric power generation for co-digestion mixture 5 .
Mixture 6, based on $90 \%$ of pork slurry, chicken dung and cow dung and $10 \%$ of glycerine, takes advantage of the surplus glycerine from the biodiesel industry, and promotes the deployment of co-digestion power plants specially in the Southwest part of Spain, as it can be seen in Figure 5.

Figures 6 and 7 reflect the strong synergies between animal waste and whey. It can be observed that they constitute basically two residues with different properties from the same origin, coexisting in the same areas, and favoring their use in co-digestion systems.

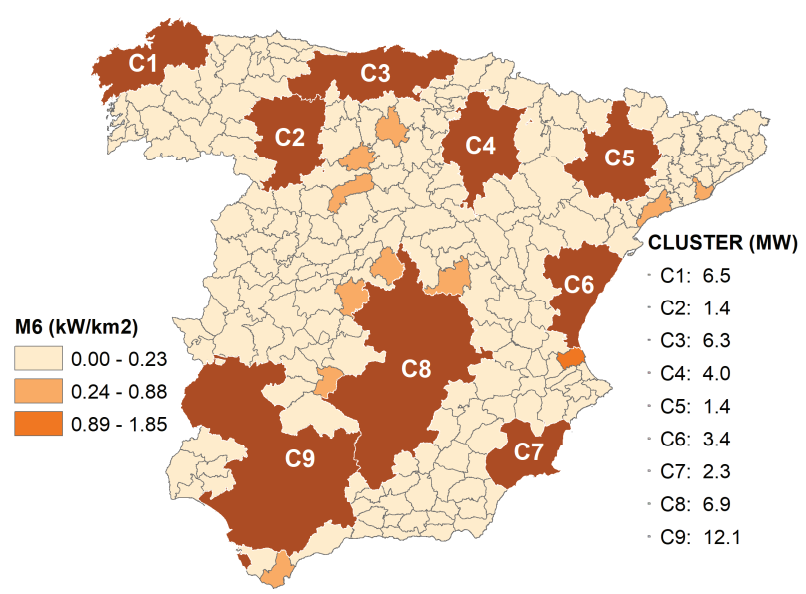

Figure 5. Geographical distribution of the electric power generation for co-digestion mixture 6 .

Mixtures 7 (45\% of cow dung and $55 \%$ of whey) and 8 (45\% of cow dung and $55 \%$ and whey) are two options that work in a similar way, but the different input rates change the saturation point of the mixtures. It should be noticed that only two cluster areas identified for these mixtures exceed the $2 \mathrm{MW}$ threshold for economically feasible centralized power generation exploitation. However, due to the plenty of the input raw material, both mixtures are very sustainable options for improving the power generation planning, without hesitation.

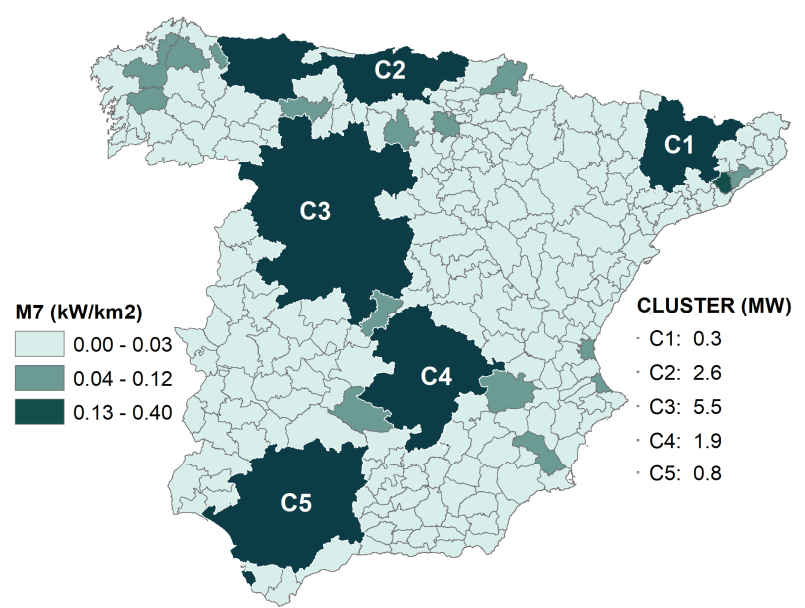

Figure 6. Geographical distribution of the electric power generation for co-digestion mixture 7. 
Table III shows the final results for each mixture, highlighting the electric generation potential for centralized and distributed generation, while Table IV shows the most constraining input raw material for each case.



Figure 7. Geographical distribution of the electric power generation for co-digestion mixture 8 .

Table III. - Estimated power generation potential for each selected co-digestion mixture. Source: own elaboration.

\begin{tabular}{|c|r|r|r|r|}
\hline ID & $\begin{array}{c}\text { TOTAL } \\
\text { ELECTRIC } \\
\text { POWER } \\
\text { POTENTIAL } \\
\text { (MW) }\end{array}$ & $\begin{array}{c}\text { NUMBER } \\
\text { OF } \\
\text { CLUSTERS }\end{array}$ & $\begin{array}{c}\text { AVERAGE } \\
\text { POWER } \\
\text { POTENTIAL } \\
\text { FOR } \\
\text { CENTRALIZED } \\
\text { GENERATION } \\
\text { (MW) }\end{array}$ & $\begin{array}{c}\text { POWER } \\
\text { POTENTIAL } \\
\text { FOR } \\
\text { DISTRIBUTED } \\
\text { GENERATION } \\
\text { (MW) }\end{array}$ \\
\hline 1 & 174.87 & 5 & 17.22 & 88.78 \\
\hline 2 & Negligible & 0 & 0.00 & Negligible \\
\hline 3 & Negligible & 0 & 0.00 & Negligible \\
\hline 4 & 146.34 & 7 & 12.36 & 59.80 \\
\hline 5 & 139.54 & 5 & 12.06 & 79.24 \\
\hline 6 & 68.50 & 9 & 4.93 & 24.09 \\
\hline 7 & 17.75 & 5 & 2.23 & 6.60 \\
\hline 8 & 22.13 & 5 & 2.52 & 9.51 \\
\hline AVG & $\mathbf{9 4 . 8 6}$ & $\mathbf{6}$ & $\mathbf{8 . 2 5}$ & $\mathbf{4 4 . 6 7}$ \\
\hline
\end{tabular}

Table IV. - Constraining inputs and sensibility for each selected co-digestion mixture. Source: own elaboration.

\begin{tabular}{|r|l|r|}
\hline ID & \multicolumn{1}{|c|}{ CONSTRAINING INPUT } & $\begin{array}{r}\text { SENSIBILITY } \\
(\mathbf{W} / \mathbf{t})\end{array}$ \\
\hline 1 & Pork slurry & 9.41 \\
\hline 2 & N/A & N/A \\
\hline 3 & N/A & N/A \\
\hline 4 & Agricultural residuals & 45.94 \\
\hline 5 & Glycerine & 181.45 \\
\hline 6 & Glycerine & 252.01 \\
\hline 7 & Cow dung & 6.81 \\
\hline 8 & Cow dung & 28.16 \\
\hline
\end{tabular}

\section{Conclusions}

In order to promote the deployment of sustainable and renewable energy sources it results mandatory the development of optimal resources allocation, especially for the evaluation of the potential of co-digestion-based power plants. Thus, in this study, thanks to a GIS-based approach, livestock and agricultural waste have been energetic valorized by configuring the highest biogas production mixtures and geographically locating the most profitable ones, distinguishing between centralized and distributed generation potential.

It has been observed that 8 mixtures could be feasible for electric power generation in Spain, highlighting mixture 4 which combines $80 \%$ of pork slurry, chicken and cow dung and $20 \%$ of agricultural waste.

The global estimated electric power generation by codigestion-based power plants in Spain can achieve between $175 \mathrm{MW}$ and $550 \mathrm{MW}$ (from 2.1 up to 6.5 times the current installed capacity of this sort of RES power plants), being between 86.5 MW and 304.5 MW centralized power generation (average power plant's rated power of $8.25 \mathrm{MW}$ ) and between $88.8 \mathrm{MW}$ and 248.0 MW distributed generation (with and average power potential of $44.7 \mathrm{MW}$ ).

The proposed GIS approach for optimal resource allocation and clustering results a key point to define the location of the facilities as well as their sizing, following medium-term energy planning strategies, since the optimal sites can vary depending on the resource competition.

The quantity, variability and heterogeneity of the input raw materials for co-digestion processes make essential the development of this sort of integrated tools to assess the problem. Moreover, the presented methodology has the added value of provide the allocation of the resources considering minimum transport costs.

Based on the proposed methodology, future research works can optimize the location and sizing of codigestion power plants considering geographical restrictions and the coexistence of power plants fed by different mixtures competing for the input resources.

\section{Acknowledgement}

This paper has been published thanks to the support of the Laboratorio de Inspección Técnica de la Escuela de Minas (LITEM), Universidad de León (Spain). The authors want to thank all contributors to the project, and to the Conference Chair and reviewers for their valuable comments to increase the overall quality of the manuscript.

\section{References}

[1] OECD, "OECD Environmental Outlook to 2050," OECD iLibrary. [Online]. Available: https://read.oecdilibrary.org/environment/oecd-environmental-outlook-to2050_9789264122246-en. [Accessed: 31-Oct-2018].

[2] "EBA Statistical Report 2017 - European Biogas AssociationEuropean Biogas Association.”. 
[3] X. E. Castells, Tratamiento y valorización energética de residuos. Ediciones Díaz de Santos, 2005.

[4] S. G. Pavlostathis and E. Giraldo-Gomez, "Kinetics of Anaerobic Treatment," Water Sci Technol, vol. 24, no. 8, pp. 35-59, Oct. 1991.

[5] Flotats X., Fernández, B., Pascual, A., Ruiz, B. y Gómez, P., "Situación y potencial de generación de biogás," Idae, Madrid, Spain, 2011.

[6] H. Rodhe, "A comparison of the contribution of various gases to the greenhouse effect," Science, vol. 248, no. 4960 , pp. 1217-1219, 1990.

[7] C. H. Burton and C. Turner, Manure management: Treatment strategies for sustainable agriculture. Editions Quae, 2003.

[8] M. Berglund and P. Börjesson, "Assessment of energy performance in the life-cycle of biogas production," Biomass and Bioenergy, vol. 30, no. 3, pp. 254-266, Mar. 2006.

[9] "PRETOR." [Online]. Available: https://sedeaplicaciones.minetur.gob.es/Pretor/Vista/Inform es/InformesInstalaciones.aspx. [Accessed: 14-Oct-2018].

[10] "Real Decreto 661/2007, de 25 de mayo, por el que se regula la actividad de producción de energía eléctrica en régimen especial.," 2007. [Online]. Available: https://www.boe.es/buscar/act.php?id=BOE-A-2007-10556 [Accessed: 16-Oct-2018].

[11] "Probiogas," Probiogás, 2011. [Online]. Available: http://www.probiogas.es/. [Accessed: 23-Sep-2018].

[12] Ministerio de medio ambiente y medio rural y marino, "El sector del biogás agroindustrial en España," Madrid, Spain, Sep. 2010.
[13] Y. R. Chen, "Kinetic analysis of anaerobic digestion of pig manure and its design implications," Agricultural Wastes, vol. 8, no. 2, pp. 65-81, Jan. 1983.

[14] P. Harris, "Biowatts - Online Biogas Calculator \& Biomass Marketplace - index." [Online]. Available: http://www.biowattsonline.com/anaerobic_digestion_kinet ics calculator/index. [Accessed: 05-Nov-2018].

[15] B. K. T. Samarasiri, S. W. S. Samarakoon, P. G. Rathnasiri, and S. H. P. Gunawardena, "Mechanistic model for electricity generation via biomethane production through anaerobic digestion of organic fraction of municipal solid waste generated in Sri Lanka," in 2017 Moratuwa Engineering Research Conference (MERCon), 2017, pp. 407-412.

[16] C. Bidart, M. Fröhling, and F. Schultmann, "Livestock manure and crop residue for energy generation: Macroassessment at a national scale," Renewable and Sustainable Energy Reviews, vol. 38, pp. 537-550, Oct. 2014.

[17] N. Muñoz Soler, "Valorización de Residuos de la Industria Agroalimentaria. Codigestión de estiércol de vacuno lechero y suero de quesería.," Universidad de Cantabria, Cantabria, 2017.

[18] V. Dopico, "Propuesta de tarifas de coste de transporte de mercancías," 2005. [Online]. Available:

https://docplayer.es/5597155-Propuesta-de-tarifas-decoste-de-transporte-de-mercancias.html. [Accessed: 29Nov-2018].

[19] A. J. Wood and B. F. Wollenberg, Power, generation, operation and control, Second. Tornto: John Wiley, 1996. 